\title{
Sensitive detection of serum antibodies in the cane toad Bufo marinus
}

\author{
R. J. Whittington ${ }^{1, *}$, R. Speare ${ }^{2}$ \\ ${ }^{1}$ Elizabeth Macarthur Agricultural Institute, Private Mail Bag 8, Camden, NSW 2570, Australia \\ ${ }^{2}$ Department of Public Health and Tropical Medicine, James Cook University, Townsville, Queensland 4811, Australia
}

\begin{abstract}
Populations of both IgM and IgG antibodies were induced in the serum of cane toads Bufo marinus by immunisation with the $T$-dependent antigen ovalbumin, and then purified by molecular sieving and ion-exchange chromatography. Antisera against purified IgG were prepared in rabbits and sheep and used in enzyme-linked immunosorbent assays (ELISA) to study the kinetics of the humoral response against the model antigen in the cane toad. The applications of ELISA in the study of the seroepidemiology of putative cane toad pathogens such as ranaviruses and Mucor amphibiorum are discussed.
\end{abstract}

KEY WORDS: Bufo marinus - Immunology $\cdot$ Antibodies $\cdot$ ELISA $\cdot$ Serology Disease $\cdot$ Amphibian

\section{INTRODUCTION}

The cane or marine toad Bufo marinus was introduced to northern Australia in 1935 as a biological control agent for 2 pests of sugar cane: the grey backed beetle Dermolepida albohirtun and the frenchi beetle Lepidiota frenchi. The toad spread rapidly and became a pest itself (van Beurden 1981). In 1986 systematic studies commenced to investigate diseases and ecology of the cane toad in Australia and its native South American range with the aim of discovering a biological control agent. Prior to commencement of the project a number of infectious agents had been described from $B$. marinus, but few offered promise as control agents (Speare 1990).

In 1989 a new iridovirus in the genus Ranavirus, the Bohle iridovirus (BIV), was discovered in ornate burrowing frogs Limnodynastes ornatus in north Queensland (Speare \& Smith 1992, Hengstberger et al. 1993). BIV killed cane toads after inoculation and by horizontal transmission in experimental situations (R.S. unpubl. data). However, ranaviruses were not isolated from about 30 wild adult toads and from 3 batches of

•E-mail: whittir@quord.agric.nsw.gov.au wild cane toad tadpoles in the Townsville area, the region where BIV was originally isolated (R.S. unpubl. data). A serological test capable of detecting antibodies to ranaviruses would enable surveys to be made of the prevalence of antibodies against these viruses in the free-ranging population, but such a test is not currently available.

Speare et al. (1991) using electron microscopy detected a large iridovirus in red blood cells and macrophages of Bufo marinus in Costa Rica. The epidemiology of this agent is unknown. The virus is similar to Frog Erythrocytic Virus (FEV) of Rana clamitrans and Rana catesbeiana in Canada (Gruia-Gray et al. 1989). FEV could not be grown in cell culture (Granhoff 1989, Gruia-Gray et al. 1989). Availability of a reliable serological test will be of immense value in studies on the putative iridovirus from $B$. marinus in Costa Rica and other large idiroviruses of amphibians.

In Australia cane toads are naturally infected with the pathogenic fungus Mucor amphibiorum (Speare et al. 1994). M. amphibiorum occurs in the soil and by studies using slaughter and gross pathology, the fungus has been found in cane toads over most of their range. Little is known of the epidemiology of this infection. A test to detect antibodies to $M$. amphibiorum 
would enable the epidemiology of this infection to be more fully investigated.

Epidemiological and histopathological evidence suggested that the progressive decline in several species of rainforest frogs in Queensland was due to an infectious agent and ranaviruses were suggested as potential agents (Laurance et al. 1996). BIV was shown to be pathogenic for juveniles of 2 native Australian frog species, Limnodynastes terraereginae and Litoria latopalmata (Cullen et al. 1995), but this ranavirus was not pathogenic for adults of the dainty tree frog Litoria gracilenta (R.J.W. unpubl. data). Recently, a morphologically similar agent was associated with mortalities of wild common frogs Rana temporaria in Surrey, United Kingdom (Drury et al. 1995). A simple serological test capable of detecting antibodies to infectious agents would enable populations of free-living frogs to be examined.

Serology is used widely to evaluate the presence, frequency and spread of infectious agents in mammals. This is made possible by our detailed understanding of the ontogeny and kinetics of humoral immune responses in mammals and the availability of a wide range of serological methods. Although there are only 2 studies in which serology was used to study infectious diseases in amphibians (Bennet 1978, Al-Yaman \& Ingram 1987, Ingram \& Al-Yaman 1987), serology is likely to be a useful tool because the humoral immune system of the amphibia is well developed. Studies in Bufo marinus, the bullfrog Rana catesbeiana and the clawed toad Xenopus laevis have shown that in common with higher vertebrates, the initial response to T-dependent antigens includes production of 19S IgM antibodies, followed by isotype switch to IgG with affinity maturation and an anamnestic response after subsequent exposure to antigen (Marchalonis \& Edelman 1966, Legler et al. 1969, Du Pasquier \& Haimovich 1976). The response to $T$-independent antigens is dominated by the IgM class of antibody, although there is an IgG component and there is no anamnestic response, again in keeping with higher vertebrates (Diener \& Nossal 1966, Legler et al. 1969, Collie et al. 1975, Marchalonis \& Germain 1980). High titres of antibody are achieved and these may persist for many weeks after a single exposure to antigen. Furthermore, and as distinct from mammals, the amphibia are responsive to antigen at a very early stage of ontogeny. Larval frogs and toads are capable of humoral responses which persist and mature through metamorphosis (Cooper \& Hildemann 1965, Du Pasquier \& Haimovich 1976). Serum antibodies have been detected in amphibia following inoculation with antigens as diverse as bacteriophage, bacterial flagellae, goldfish serum, foreign immunoglobulin chains, equine erythrocytes, bacterial lipopolysaccharide and bovine serum albumin using serological techniques including double immunodiffusion, indirect haemagglutination, haemagglutination inhibition and viral neutralisation.

Ideally a serological test for use in epidemiological studies should be highly sensitive, as some individuals will be in the early phase of a humoral response while others will be in a decline phase and consequently the concentrations of specific immunoglobulins may be low. Of the available serological tests, only primary antigen-antibody binding assays such as the enzymelinked immunosorbent assay (ELISA) offer high sensitivity combined with reproducibility, stability of reagents, non-radioactivity, low cost and the ability to be used for almost all types of antigens. The common format of ELISA for detection of antibody requires a reagent capable of binding to the antibody of the species being evaluated; this is generally an antiimmunoglobulin antibody raised in another species, but may be a substance such as staphylococcal protein A which binds to the $\mathrm{Fc}$ region of the relevant immunoglobulin molecule.

The aims of this study were to purify the serum immunoglobulins of Bufo marinus, to produce mammalian anti-B. marinus immunoglobulins for use in ELISA, to evaluate the binding of $B$. marinus antibodies to staphylococcal protein $A$ and to evaluate ELISA as a means of detecting humoral responses in B. marinus against a model T-dependent antigen, ovalbumin.

\section{MATERIALS AND METHODS}

Source and husbandry of cane toads. Free-ranging adult cane toads were collected from near peoples' homes in Townsville, north Queensland, during the dry season from September to December 1993. Mean daily temperatures ranged from 23.7 to $27.5^{\circ} \mathrm{C}$, humidity ranged from 60 to $86 \%$ and total rainfall was $227 \mathrm{~mm}$. The toads consisted of 17 females and 7 males with snout-urostyle lengths of 88.2 to $120 \mathrm{~mm}$ (range) and weights of 90.7 to $250.9 \mathrm{~g}$. The toads were kept in an outdoor enclosure on soil and fed commercial dog kibble supplemented with flying insects attracted and killed by an electric insect killer suspended above the enclosure. Hydration was maintained by self immersion in a shallow pond in the enclosure and periodic watering with a garden sprinkler.

Toads were manually restrained by a single operator who collected blood from the heart with a $1 \mathrm{ml}$ syringe and a 26 gauge needle. At each venipuncture 0.3 to $0.8 \mathrm{ml}$ of blood was collected without apparent ill effects.

Immunisation of cane toads. On 3 occasions (Days 1, 19 and 37$)$, toads $(n=24)$ were immunised by injection 
into the subcutaneous lymph sinuses of $1 \mathrm{mg}$ ovalbumin in $0.05 \mathrm{ml}$ PBS (phosphate buffered saline) homogenised with $0.05 \mathrm{ml}$ Freund's complete adjuvant. Blood was collected at these times and at Day 167. Serum, undiluted or diluted 1:10 in $25 \mathrm{mM}$ Tris- $\mathrm{HCl} \mathrm{pH} 7.2,0.15 \mathrm{M} \mathrm{NaCl}$ and $45 \%$ glycerol, was stored at $-20^{\circ} \mathrm{C}$.

Purification of antibodies from cane toad serum. Antibodies were purified from cane toad serum using methods given by Whittington (1993). Briefly, $0.1 \mathrm{ml}$ of serum collected from each toad at Day 167 after immunisation with ovalbumin was pooled and separated in $25 \mathrm{mM}$ Tris $\mathrm{HCl} \mathrm{pH} 7.2,0.15 \mathrm{M} \mathrm{NaCl}, 0.01 \%$ (w/v) $\mathrm{NaN}_{3}$ (Tris Saline, TS) by molecular sieving through a $94 \times 2.5 \mathrm{~cm}$ Sephacryl S300 (Pharmacia) column that was calibrated with ovine IgG (Selenus), bovine IgM (Sigma) and blue dextran 2000 (Pharmacia) to enable estimation of molecular weight. The resulting fractions were analysed by ELISA using an antiserum raised in a rabit against cane toad serum (see below). Fractions containing ovalbumin-binding activity were pooled, dialysed against $25 \mathrm{mM}$ Tris$\mathrm{HCl}$ pH 7.2 (starting buffer) and subjected to ionexchange chromatography in a continuous gradient of 0 to $0.5 \mathrm{M}$ followed by another of 0 to $0.3 \mathrm{M} \mathrm{NaCl}$ on DEAE-sepharose CL-6B (Pharmacia). Fractions containing ovalbumin-binding activity were pooled, dialysed against TS, concentrated by dialysis against carboxymethylcellulose (Aquacide II, Calbiochem) and stored at $4{ }^{\circ} \mathrm{C}$. In addition, pooled fractions were passed through a column containing ovalbumin conjugated to $\mathrm{CNBr}$-activated sepharose-4B and eluted with $0.1 \mathrm{M}$ glycine $0.5 \mathrm{M} \mathrm{NaCl}, \mathrm{pH}$ 3. Purified immunoglobulins were assessed by sodium-dodecyl sulphate polyacrylamide gel electrophoresis (SDSPAGE).

Affinity of cane toad immunoglobulins for staphylococcal protein A. Pooled immune cane toad serum (1 ml) from Day 167 was diluted 1:1 in TS and passed through a $5 \mathrm{ml}$ bed of protein A sepharose (Pharmacia) at $10 \mathrm{ml} \mathrm{cm}^{2} \mathrm{~h}^{-1}$. After complete passage of the excluded material the column was equilibrated with TS before eluting with $0.1 \mathrm{M}$ glycine $0.5 \mathrm{M} \mathrm{NaCl}$, $\mathrm{pH} 3$.

Preparation of anti- $B$. marinus antisera in rabbits and sheep. Rabbits were immunised subcutaneously with cane toad serum ( $\mathrm{n}=1)(0.75 \mathrm{ml}$ homogenised with $0.75 \mathrm{ml}$ Freund's complete adjuvant) or purified cane toad immunoglobulin $(n=2)(125$ to $450 \mu \mathrm{g}$ in $1 \mathrm{ml}$ saline homogenised with $1 \mathrm{ml}$ Freund's complete adjuvant) on 2 occasions 1 mo apart. Sheep $(n=2)$ were given purified immunoglobulin as above.

Enzyme-linked immunosorbent assay. Ovalbumin was diluted in borate buffer $(100 \mathrm{mM}$ boric acid, $25 \mathrm{mM}$ disodium tetraborate, $75 \mathrm{mM} \mathrm{NaCl}, \mathrm{pH}$ 8.4) to $1 \mathrm{mg} \mathrm{ml}^{-1}, 100 \mu \mathrm{l}$ was added to each well of a microtitre plate (Linbro, Flow ICN) and the plate was incubated overnight at $4^{\circ} \mathrm{C}$. After washing 5 times in distilled water with $0.05 \%(\mathrm{v} / \mathrm{v})$ Tween 20 , cane toad serum diluted $1: 200$ in $0.1 \%(\mathrm{w} / \mathrm{v})$ gelatin in PBS $\mathrm{pH} 7.4$ and $0.05 \%(\mathrm{v} / \mathrm{v})$ Tween 20 (PBSTG) or undiluted chromatography fractions were added to wells and incubated for $90 \mathrm{~min}$ at room temperature (RT) After washing, rabbit or sheep antiserum was added and the plate was incubated for $90 \mathrm{~min}$ at RT. After washing, an appropriate horseradish peroxidase conjugate diluted in PBSTG was added and incubated for $90 \mathrm{~min}$ at RT. Conjugates were either protein AHRP (Biorad) for detection of bound rabbit antibodies or rabbit-anti-sheep immunoglobulin-HRP (KPL Laboratories) for detection of bound sheep antibodies. After washing, the chromogen 2,2'-azino-bis(3-ethylbenzthiazoline-6-sulfonic acid) (ABTS) was added and incubated for $20 \mathrm{~min}$ at RT, before stopping the reaction with $50 \mu \mathrm{l} \mathrm{well}{ }^{-1}$ of $0.01 \%(\mathrm{w} / \mathrm{v})$ sodium azide in $0.1 \mathrm{M}$ citric acid and reading of optical density (OD) at $405 \mathrm{~nm}$. ELISA OD is referred to as antibody level. Antibody level was considered to be elevated in an individual when ELISA OD had increased by at least 1.5 -fold over the pre-immunisation value.

Optimal incubation conditions and dilutions of reagents were chosen after chequerboard titration so as to maximise the ratio of $O D$ between the sera of immunised cane toads compared with their preimmune sera.

\section{RESULTS}

\section{Purification of cane toad immunoglobulins}

Cane toad serum was resolved into 4 principal absorbance peaks at $280 \mathrm{~nm}\left(\mathrm{~A}_{280}\right)$ by molecular sieving on Sephacryl S300. Ovalbumin-binding activity was present as 2 peaks, one in the leading edge of the first $A_{280}$ peak and the other in the second $A_{280}$ peak. These represented molecular weights of approx. 700000 and 145000 and therefore correspond to IgM and IgG respectively (Fig. 1). The IgM peak was not studied further due to the small yield of protein. The IgG peak was purified by ionexchange chromatography. The presence of bands consistent with immunoglobulin heavy and light chains and minor amounts of other material was confirmed by SDS-PAGE (Fig. 2). Ion-exchange purified immunoglobulins could not be purified further by affinity chromatography on ovalbumin-sepharose due to apparent failure of interaction of anti-ovalbumin antibodies with the matrix. 


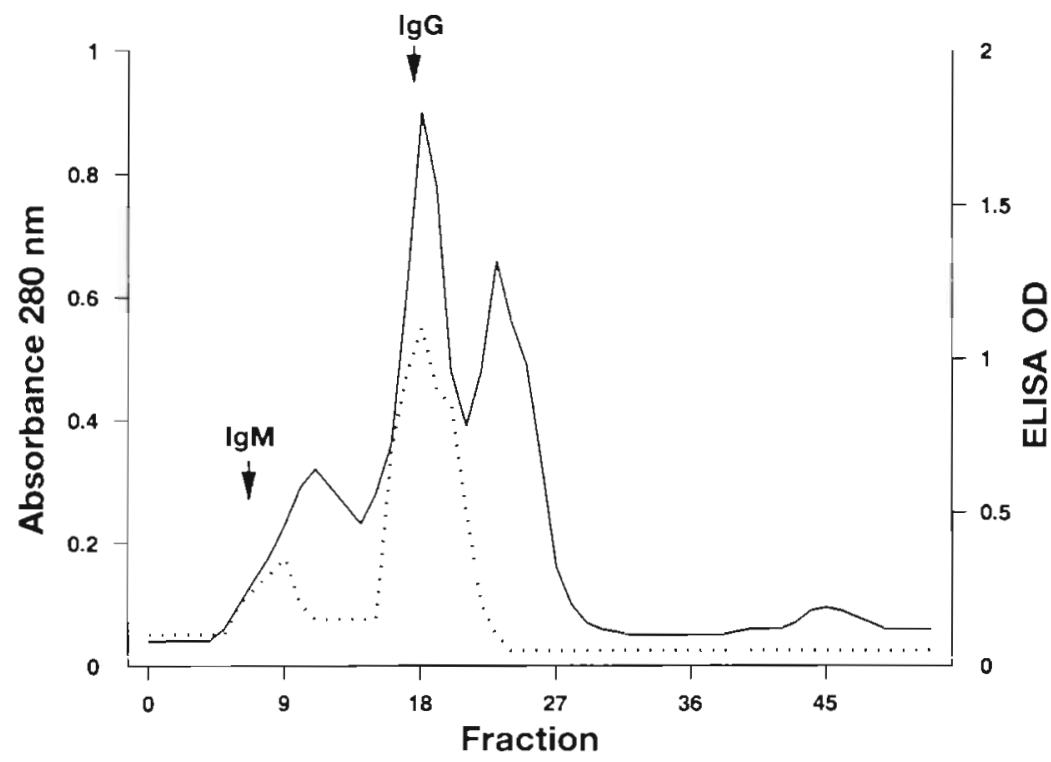

Fig. 1. Chromatogram on Sephacryl S300 of pooled serum collected from Bufo marinus $167 \mathrm{~d}$ after immunisation with ovalbumin. Solid line: absorbance at $280 \mathrm{~nm}_{\text {; }}$ broken line ELISA OD representing ovalbumin binding activity. The elution of bovine IgM and ovine IgG is indicated by arrows

\section{Affinity of cane toad immunoglobulins for staphylococcal protein A}

All components of cane toad serum were excluded from the protein A column, indicating failure of binding of cane toad immunoglobulins to protein $A$ under the conditions used.

\section{Optimisation of ELISA}

Antibodies against the purified cane toad immunoglobulins were detected in rabbits and sheep by double immunodiffusion $4 \mathrm{wk}$ after initial immunisation. Serum collected 2 wk after the second immunisation was used for ELISA. The optimal dilutions of rabbit and sheep antisera were 1:200 and 1:1600 respectively. One of 2 sheep had pre-existing antibody which reacted with cane toad immunoglobulins and was excluded from the study. With these dilutions of rabbit and sheep antisera, optimal dilutions of the conjugates protein A-HRP and rabbit-anti-sheep immunoglobulin-HRP were 1:2000 and 1:3000 respectively.

\section{Detection of serum antibodies against ovalbumin in immunised cane toads using ELISA}

Elevated levels of antibodies against ovalbumin were detected in many cane toads at the first bleed after immunisation (Day 19) (Table 1, Fig. 3). Antibody levels increased more rapidly to Day 37 and remained elevated at Day 167 (Fig. 3). There was variation in the magnitude of the antibody response between cane toads, some appearing to have delayed responses to immunisation, but the extent of this variation depended on which mammalian immune serum had been used in the ELISA (Table 1). While responses of greater magnitude overall were detected with rabbit anti-cane toad immunoglobulin (up to 20.4-fold) than with sheep anti-cane toad immunoglobulin (up to 7.9fold) (Fig. 3), both reagents detected a similar proportion of cane toads with elevated antibody levels at each time (Table 1). The ELISA with rabbit anti-cane toad whole serum was relatively insensitive during the initial humoral response and again after the peak immune response. The greatest increase in antibody

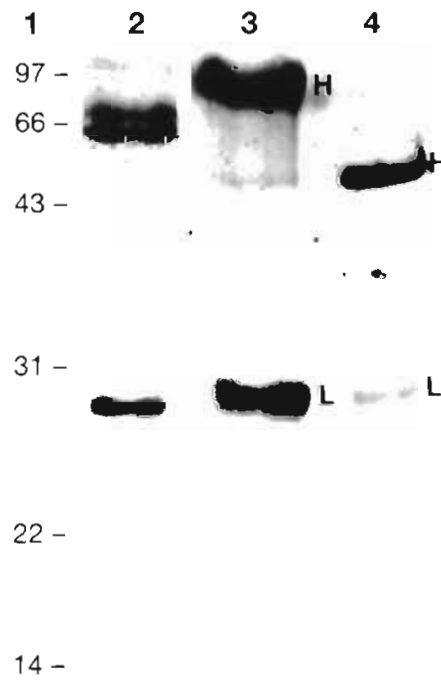

Fig. 2. SDS-PAGE gel (12\%) stained with Coomassie Brilliant Blue. Lane 1. molecular weight markers. Lane 2: Bufo marinus IgG. Lane 3: bovine IgM. Lane 4: ovine $\operatorname{IgG}$. $\mathrm{H}=$ heavy chain, $\mathrm{L}=$ light chain 
Table 1. Comparison of 3 mammalian anti-Bufo marinus immunoglobulin reagents used in ELISA. Data are the percentage of cane toads $(n=24)$ with elevated antibody levels after immunisation with ovalbumin

\begin{tabular}{|lccc|}
\hline \multirow{2}{*}{ Reagent used in ELISA } & \multicolumn{3}{c|}{ Time after first immunisation } \\
& Day 19 & Day 37 & Day 167 \\
\hline Rabbit anti-cane toad immunoglobulin & 60 & 94 & 100 \\
Sheep anti-cane toad immunoglobulin & 65 & 89 & $100^{\circ}$ \\
Rabbit anti-cane toad whole serum & 40 & 88 & $73^{\cdot}$ \\
$\cdot p<0.05$, Chi-square test & & & \\
\hline
\end{tabular}

level was 4.8-fold and some cane toads appeared to have not responded to immunisation (Table 1, Fig. 3).

\section{DISCUSSION}

The antibodies induced by immunisation of cane toads with ovalbumin included both $\operatorname{IgM}$ and $\operatorname{IgG}$ classes of immunoglobulin but the latter predominated $167 \mathrm{~d}$ after immunisation (Fig. 1). The purified immunoglobulins had L chains with mobilities in SDS-PAGE gels comparable to those of mammalian L chains. The Bufo marinus gamma-H chains were slightly retarded

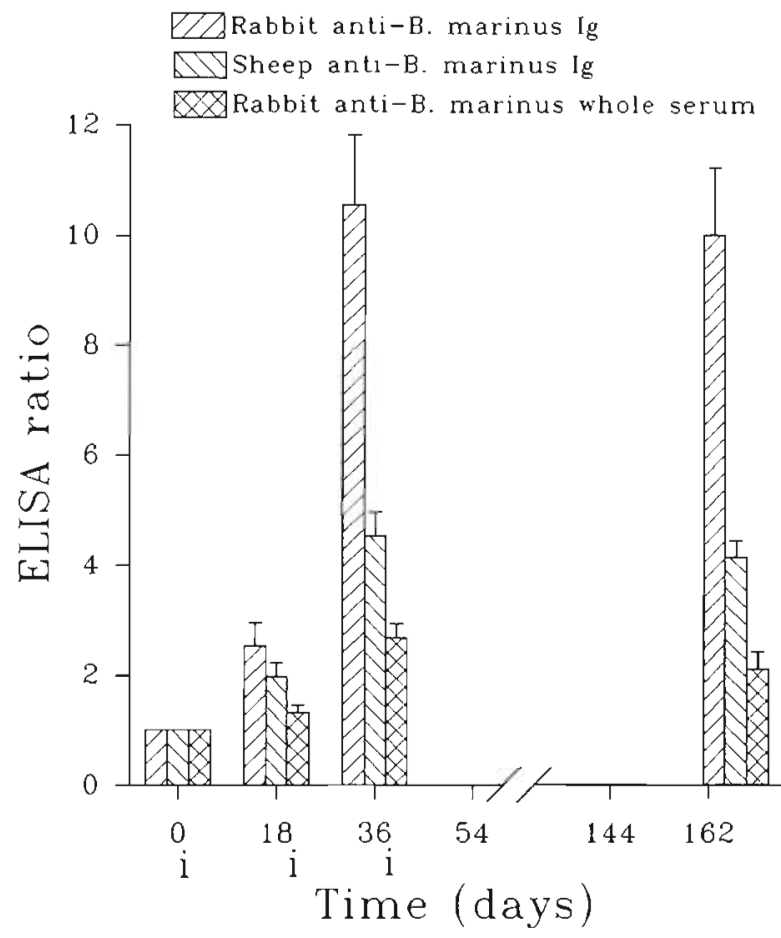

Fig. 3. Antibody responses detected by ELISA in 24 cane toads Bufo marinus which were immunised with ovalbumin at the 3 times shown (i). Three ELISA assays with the following reagents were used: rabbit anti-cane toad whole serum; rabbit anti-cane toad immunoglobulin and sheep anti-cane toad immunoglobulin. Data are means $\pm \mathrm{SE}$ in mobility compared with mammalian $\mathrm{H}$ chains, indicating a higher molecular weight. These results are consistent with those of Atwell \& Marchalonis (1975), who reported that the low molecular weight immunoglobulins of anvrans were distinct from IgG of mammals. These molecules are now referred to by immunologists as IgY (Warr et al. 1995). However, for convenience, the low molecular weight immunoglobulin of the cane toad will be referred to here as IgG.

We purified only IgG and raised antisera against it in rabbits and sheep. These antisera would be expected to be more useful in seroepidemiological studies than anti-IgM reagents for 3 reasons. Firstly, most antigens are $\mathrm{T}$-dependent and stimulate an IgG response. Secondly, substantial IgG responses appear to occur in the primary immune response in B. marinus (Diener \& Nossal 1966). Thirdly, these antisera would react with both IgG and IgM classes of immunoglobulin through recognition of common $L$ chain antigenic determinants. The stimulation of an immune response dominated by IgG indicates clearly that ovalbumin is a T-dependent antigen in $B$. marinus as it is in other species. To obtain higher yields of $B$. marinus IgM for development of an isotype-specific anti-immunoglobulin reagent, the use of a $\mathrm{T}$-independent antigen would be beneficial. An anti-IgM reagent might be useful to study humoral responses during experimental infections with putative pathogens

When incorporated in an indirect ELISA to measure antibodies against ovalbumin, the rabbit anti-cane toad immunoglobulin reagents resulted in greater analytical sensitivity than the matching sheep reagent. This was partly due to lower levels of background reactivity with the former reagents. However, both reagents appeared to detect seroconversion in Bufo marinus with equal facility, indicating that both would be useful if incorporated into ELISA for seroepidemiological purposes. Enzyme conjugates with protein A are not applicable for $B$. marinus ELISA as protein $A$ was found to have low affinity for $B$. marinus immunoglobulins.

There is only 1 earlier study on the use of ELISA to measure amphibian immunoglobulins (Al-Yaman \& Ingram 1987, Ingram \& Al-Yaman 1987). This ELISA was shown to be 1.5 to 3.5 times more sensitive than secondary antigen-antibody binding assays: direct agglutination, indirect haemagglutination and complement fixation. The principal reagent for detection of toad antibody was a rabbit antiserum against whole toad serum rather than one against toad immunoglobulin. Our approach was to develop a more specific reagent which would be likely to result in an assay of 
greater sensitivity. This was achieved. Greater sensitivity was due to avoidance of non-antigen-antibody interactions and greater specific activity. This will result in the ability to set a relatively low positive-negative cut-off for the signal obtained in ELISA when these reagents are applied to the study of infectious disease.

These results indicate that ELISA is a useful technique for measurement of specific serum antibodies in Bufo marinus. Humoral responses were detected in all cane toads after immunisation with ovalbumin. The kinetics of the response resembled those observed in cane toads immunised with other antigens (Evans et al. 1966), although responses were prolonged in the present study due to the use of an oil adjuvant.

Two studies have demonstrated humoral responses to infectious agents in amphibians. Ingram \& AlYaman (1987) measured antibodies against the trypanosomatid flagellate Crithidia fasciculata in the serum of Bufo viridus by ELISA, and Bennet (1978) found precipitating antibodies using double immunodiffusion in $B$. marinus which were infected with spargana. The ELISA described here can be readily adapted to detect antibody responses against pathogens affecting cane toads such as BIV (Speare \& Smith 1992, Hengstberger et al. 1993) and the fungus Mucor amphibiorum (Speare et al. 1994), simply by replacing ovalbumin with a relevant antigen. For detection of antibodies against BIV in B. marinus, a capture antibody is required to link the antigen to the solid phase. The format of the ELISA for the related ranavirus epizootic haematopoietic necrosis virus (Whittington et al. 1994) would be followed using the sheep anti-B. marinus immunoglobulin reagent plus an anti-sheep immunoglobulin-enzyme conjugate, or alternatively using an enzyme conjugate of the rabbit reagent. As a rabbit capture antibody is not required in ELISA for M. amphibiorum antibodies (R.J.W. unpubl. data), the rabbit anti-B. marinus immunoglobulin would be used as the second antibody, with an anti-rabbit immunoglobulin-enzyme conjugate.

Seroepidemiological study of infectious agents which are known or suspected to be endemic in the Australian cane toad population will be facilitated by the methods described here as will screening of the cane toad population for agents which may be contemplated for inclusion in a biological control programme. For example, studies of Bufo marinus in Central and South America have detected other iridoviruses (Speare et al. 1991, J. Humphrey pers. comm.), but work on epidemiology has been limited by the complexity of viral detection. Similar studies of other amphibian species will enable development of tools to study the role of infectious agents in the decline of frog populations
Acknowledgements. The authors gratefully acknowledge the assistance of Toby Speare and Christine Kearns with care of cane toads and some of the laboratory assays.

\section{LITERATURE CITED}

Al-Yaman F, Ingram GA (1987) The primary immune response of the green toad (Bufo viridis) to challenge with Crithidia fasciculata. Microbiol Immunol 31:571-582

Atwell JL, Marchalonis JJ (1975) Phylogenetic emergence of immunoglobulin classes distinct from IgM. J Immunogen $1: 367-391$

Bennett LJ (1978) The immunological responses of amphibia to Australian spargana. J Parasitol 64:756-759

Collie MH, Turner RJ, Manning MJ (1975) Antibody production to lipopolysaccharide in thymectomized Xenopus. Eur J Immunol 5:426-429

Cooper EL, Hildemann WH (1965) The immune response of larval bullfrogs (Rana catesbeiana) to diverse antigens. Ann NY Acad Sci 126:647-661

Cullen BR, Owens L, Whittington RJ (1995). Experimental infection of Australian anurans (Limnodynastes terraereginae and Litoria latopalmata) with Bohle iridovirus. Dis Aquat Org 23:83-92

Diener E, Nossal GJV (1966) Phylogenetic studies on the immune response. I. Localization of antigens and immune response in the toad Bufo marinus. Immunology 10: $535-542$

Drury SEN, Gough RE, Cunningham AA (1995) Isolation of an iridovirus-like agent from common frogs (Rana temporaria). Vet $\operatorname{Rec} 137: 72-73$

Du Pasquier L, Haimovich J (1976) The antibody response during amphibian ontogeny. Immunogenetics 3:381-391

Evans EE, Kent SP, Bryant RE, Moyer M (1966) Antibody formation and immunological memory in the marine toad. In: Smith RT, Mieschen PR, Good RA (eds) Phylogeny of immunity. University of Florida Press, Gainesville, p 218-226

Granhoff A (1989) Viruses of amphibia: an historical perpective. In: Ahne W, Kurstak E (eds) Viruses of lower vertebrates. Springer Verlag, Berlin, p 3-12

Gruia-Gray J, Petric M, Desser S (1989) Ultrastructural, biochemical and biophysical properties of an erythrocytic virus of frogs from Ontario, Canada. J Wildl Dis 25: 497-506

Ingram G, Al-Yaman F (1987) A comparative assessment of four serological methods used in detection and measurement of anti-parasite antibodies in the serum of the amphibian, Bufo viridis. Int J Parasitol 18:371-377

Hengstberger SG, Hyatt AD, Speare R, Coupar BEH (1993) Comparison of epizootic haematopoietic necrosis and Bohle iridoviruses, recently isolated Australian iridoviruses. Dis Aquat Org 15:93-107

Laurance WF, McDonald KR, Speare R (1996) Epidemic disease and the catastrophic decline of Australian rainforest frogs. Conserv Biol (in press)

Legler DW, Evans EE, Weinheimer PF, Acton RT, Attleberger $\mathrm{MH}$ (1969) Immunoglobulin and complement systems of amphibian serum. In: Mizel M (ed) Biology of amphibian tumours. Springer Verlag. New York, p 169-176

Marchalonis J, Edelman GM (1966) Phylogenetic origins of antibody structure II. Immunoglobulins in the primary immune response of the bullfrog, Rana catesbiana. J Exp Med 124:901-913

Marchalonis JJ, Germain RN (1980) Antibody memory and tolerance in the marine toad (Bufo marinus). In: Manning 
MJ (ed) Phylogeny of immunological memory. Elsevier/ North-Holland Biomedical Press, Amsterdam, p 217-223

Speare R (1990) Review of the diseases of the cane toad, Bufo marinus, with comments on biological control. Aust Wildl Res 17:387-410

Speare R, Freeland WJ, Bolton SJ (1991) A possible iridovirus in erythrocytes of Bufo marinus in Costa Rica. J Wildl Dis $27: 457-462$

Speare R, Smith JR (1992) An iridovirus isolated from the ornate burrowing frog (Limnodynastes ornatus) in northern Australia. Dis Aquat Org 14:51-57

Speare R, Thomas AD, O'Shea P, Shipton WA (1994) Mucor amphibiorum in the cane toad, Bufo marinus, in Australia. J Wildl Dis 30:399-407

Responsible Subject Editor: P. Zwart, Utrecht, The Netherlands van Beurden E (1981) Bioclimatic limits to the spread of Bufo marinus in Australia: a baseline. Proc Ecol Soc Aust 11 $143-149$

Warr GW, Magor KE, Higgins DA (1995) IgY: clues to the origins of modern antibodies. Immun Today 16:392-398

Whittington RJ (1993) Purification and partial characterisation of serum immunoglobulin of the European perch (Perca fluviatilis L.). Fish Shellfish Immunol 3:331-343

Whittington RJ, Philbey A, Reddacliff GL, Macgown AR (1994) Epidemiology of epizootic haematopoietic necrosis virus (EHNV) infection in farmed rainbow trout Oncorhynchus mykiss (Walbaum). Findings based on virus isolation, antigen capture ELISA and serology. J Fish Dis $17: 205-218$

Manuscript first received: October 31, 1995

Revised version accepted: January 2, 1996 